\title{
Promoting Federalism, IWRM, and \\ Functional Approach to Water Governance under Ethiopian Water Laws
}

\begin{abstract}
Integrated functional approach to water governance in a federal state structure can avoid vertical and horizontal conflicts. There are queries on how functional approach to water governance can be promoted in the context of federal state structure. Other concerns include linkages, the meditating factor demanding for reconciling competing water uses, integrated water resources management (IWRM) and integrated river basin management (IRBM). This article assesses the existing governance framework and its suitability to promote functional approach to water governance, reconciliations and policy options. There are inconsistencies in the Constitution, Federal water management laws, river basin high councils and authority's laws, policies, strategies and the regulation that establishes and defines the powers and duties of the Ethiopian Basin Development Authority. Moreover, there are missing links and integrations, centralizing tendencies and failures to accommodate and harmonize pluralistic and diversified local practices. The water laws need to integrate both the bottom-up approach (by empowering the grassroots and bringing efficient, equitable, and sustainable use of water) and top-down form of governance (to harmonize the inter-local linkages among and within regional states). The inter-state basin governance needs reform and the over-centralized role of the government to designate water institutions should be controlled. Reconciliation is mandatory for better empowerment, cooperation and harmonization at all linkages, levels and types of inter-governmental relations.
\end{abstract}

Key terms: Federalism · IWRM-IRBM · Functional approach · Water governance linkages $\cdot$ Reconciliation $\cdot$ Harmonization

DOI http://dx.doi.org/10.4314/mlr.v13i3.3

This article is licensed under a Creative Commons Attribution-NonCommercial-

NoDerivs (CC BY-NC-ND)

Suggested citation:

Haileslassie, Zbelo (2019), 'Promoting Federalism, IWRM, and Functional

Approach to Water Governance under Ethiopian Water Laws', Mizan Law Review,

Vol. 13, No. 3, pp. 384-418

\footnotetext{
- Zbelo Haileslassie (Assistant Professor, Mekelle University School of Law); PhD candidate; LL.M in Taxation and Investment Laws; LL.B; BA in Sociology.

Email: zbelo40@gmail.com, zbelo.haileslasie@mu.edu.et

ORCID: https://orcid.org/0000-0002-2140-4421
} 


\section{Introduction}

The governance and management of water resources and the adoption of federalism have an impact to each other. ${ }^{1}$ The fluid nature of water defies the contained and isolated nature of water governance exercised by the federal units. This nature defies the decentralization of power in water governance. The effort to bring integrated water resources management (IWRM) may also fail if due care is not exerted to such management approaches. Water is the connecting factor both in territorial and ethnic federalism. ${ }^{2}$ It enshrines concurrent powers and may cause conflicts although there is power division on the basis of shared rule and self-rule.

The problem of the existing water governance in Ethiopia includes the absence of empowering legal frameworks to the grass root, absence of clear approach and the arbitrary application of some approaches without theoretical and logical base, the tendency to seek autonomy on water governancemanagement despite the fugitive nature of the water resources and fragmented jurisdictions. ${ }^{3}$ There are differences and challenges in the laws, by-laws, implementations and customary practices in applying the IWRM and integrated river basin management (IRBM). There are conflicts that threaten balanced and reconciled interests on water. ${ }^{4}$ There are practical challenges of social, economic and environmental pressures relating to stakeholders. ${ }^{5}$ There are traditional beliefs such as 'water as a gift of nature' and corresponding gaps in recognizing the role of human activities in its sustainability. Poor culture and trends of water use are among social pressures that hinder stakeholders to collaborate and participate in water resources management activities. ${ }^{6}$ As a result, there are

\section{Frequently used acronyms:}

AWBA Awash Basin Authority

IRBM Integrated river basin management

IWRM Integrated water resources management

${ }^{1}$ Ernest A. Engelbert (1957), 'Federalism and Water Resources Development', Law and Contemporary Problems, Vol. 22, No. 3, pp. 325-350

2 Juhász József (2005), 'Ethno-federalism: Challenges and Opportunities', Medunarodni Problemi 57(3).

${ }^{3}$ See for example, Awash Basin Authority (2017) Executive Summary of Strategic River Basin Plan for Awash Basin, published, available at https://www.cmpethiopia.org/ last accessed on January, 2018,

${ }^{4}$ Reta Hailu et al. (2017), 'Water institutions in the Awash basin of Ethiopia: the discrepancies between rhetoric and realities', International Journal of River Basin Management, 10.1080/15715124.2017.1387126

${ }^{5}$ Awash Basin Authority (2017), supra note 3 p, 46

${ }^{6}$ Ibid. 
conflicts of interest, lack of trust and motivations. ${ }^{7}$ In general, there is no synchronized effort to promote IWRM and functional water governance approaches through reconciliation of certain themes in the intergovernmental linkages.

Water crisis is first associated with crisis of governance. ${ }^{8}$ The need for active participation by multi-stakeholders is a pre-requisite to bring inclusive, participatory, equitable, pro-poor, innovative, efficient and effective water governance. Various studies show that the energy-water-climate, equity and efficiency can be balanced through 'collaborative governance'.

Land management in general and water management in particular are full of conflicts triggered by incompatible demands and interests at individual, communal, state and regional levels. ${ }^{10}$ Ethiopia has 12 major river basins. ${ }^{11}$ The one size fits all type of governance approach from the top does not accommodate such diversities especially in countries that have adopted federalism. Thus, this article mainly endeavours to show the need for deconstructing top-down approaches, promoting Federalism and IWRM-IRBM, and scaling up indigenous and local institutions, practices, values, knowledge etc. to the higher level of reconciliation and integration efforts.

The article mainly endeavours to answer the following research questions. How can IWRM and the functional approach to water governance be promoted in the context of federalism thereby balancing competing interests? Why are empowerment, cooperation and harmonization worthy of reconciliation? To what extent are the water laws and policies at hand consistent? What is the status of Ethiopia's water laws and policies in promoting IWRM and IRBM? What are the policy options that are helpful to institutionalize the balance of interests in water governance? The article examines policies, laws, relevant theories, literature, best practices, local and international comparative experience relating to how functional governance approach may be adopted with a view to enabling the policy options to reconcile tensions and bring about balanced allocation and utilization of water resources and IWRM. The article focuses on effective and efficient governance as a co-management approach so that local conflicts are avoided without compromising national interests. It

\footnotetext{
${ }^{7}$ Ibid.

${ }^{8}$ E. Manzungu (2014), 'Book review of Harris et al. 2014. Contemporary water governance in the Global South: Scarcity, marketization and participation'. Oxford. Water Alternatives 7(2): 434-435.

${ }^{9}$ Elizabeth Burleson (2012), 'Cooperative Federalism and Hydraulic Fracturing: A Human Right to a Clean Environment', Cornell Journal of Law and Public Policy, Vol. 22:289.

${ }^{10}$ INTOSAI-WGEA (2013), 'Land Use and Land Management Practices in Environmental Perspective', available at environmental-auditing.org last accessed on December 17, 2017

${ }^{11}$ See FDRE River Basin Councils and Authorities Proclamation No. 534/2007, Art 2(1)
} 
highlights how functional governance approach with due reconciliation efforts can promote IWRM in all linkages. The discussion is Sections 2 to 4 is preceded by a conceptual framework related with the themes and purposes of the discussion.

\section{Conceptual Framework}

Three issues are addressed in this section. The first theme is the form of federalism adopted in a given state because it will have direct impact on the efforts to promote functional governance in the higher and lower level linkages. ${ }^{12}$ Second, the section discusses definition of functional water governance which includes the direct stipulation and manifestation of water governance and water management -with due emphasis on the regulatory functions (manifestations of water management). Third, the rationale in undertaking reconciliation while empowering the grass root, cooperating and harmonizing the laws, policies and practices in inter-governmental and local linkages is highlighted. Moreover, the status of the laws (and policies), and the institutional (organizational) set ups in creating an enabling environment to promote functional water governance are examined.

\subsection{Cooperative federalism and collaborative water governance}

Halberstam and Reimann define federation as a compound polity having multiple levels of government and each has 'constitutionally grounded claims' reflected through "...some degree of organizational autonomy and direct legal authority over its citizens". ${ }^{13}$ The fundamental characteristics of federalism are: "(1) two levels of government rule on the same land and people, (2) each level has at least one area of action in which it is autonomous, and (3) there is some guarantee (even though merely a statement in the constitution) of the autonomy of each government in its own sphere". ${ }^{14}$ This definition can also be

${ }^{12}$ Dragan Bataveljić (2012), Federalism: The Concept, Development and Future, International Journal of Humanities and Social Science, Vol. 2 No. 24.See also S.M. Aliff (2015) New trends\& Models in Federalism, IOSR Journal Of Humanities And Social Science (IOSR-JHSS), Volume 20, Issue 11, Ver. I, pp. 71-79.

${ }^{13}$ D. Halberstam and M. Reimann, (eds.) (2014), Federalism and Legal Unification, Ius Gentium: Comparative Perspectives on Law and Justice 28, Springer.

${ }^{14}$ Robert I. Csehi (2011), The Changing Nature of Intergovernmental Relations in Labor Market Development - Cases for Collaborative Federalism in Canada and the EU?A paper presented at 'International Conference on Comparing Modes of Governance in Canada and the European Union: Social Policy Engagement across Complex Multilevel Systems; October 14-15; Victoria, BC. Citing William H. Riker, (1964) Federalism: Origin, Operation, Significance, Boston, Little, Brown. 
complemented by Daniel Elazar's formulation of federalism, according to which it is "a genus involving a combination of self-rule and shared-rule". ${ }^{15}$

Defining federalism based on form and substance can be helpful. ${ }^{16}$ Form, in relation to federalism refers to the formal/constitutional distribution of powers between the different levels of governance. Two different categories can be distinguished based on this category: the distribution of powers is either coordinate or concurrent. ${ }^{17}$ The first refers to a structure where competences are distributed in a fashion that each level is independently in charge of different policy areas. Usually, it is arranged in certain enumeration of powers in the constitution, so that there are no shared competences. ${ }^{18}$ Concurrency takes place when certain areas become constitutionally shared; in other words, there is a certain overlap -either administrative or legislative- between the different levels. ${ }^{19}$

The substance of federalism may be characterized as either cooperative or competitive. Cooperation refers to a relationship between the different levels of governance that is more amicable, mutually bounding, and points into a direction beneficial to the parties involved in it. In a federal system, it would mean that each level of governance has a distinct role and responsibility, and it is done in a cooperative manner. ${ }^{20}$ The nature of integration among the units and the federal government calls either for co-operative federalism ${ }^{21}$ or co-joint federalism. ${ }^{22}$

Co-operative federalism is an underlying concept that the collective cooperative interaction of the national, state, and local governments is required to solve common problems instead of making separate policies. ${ }^{23}$ The interaction

${ }^{15}$ Ibid. Citing Elazar, Daniel J. (1995), Federalism: An Overview. Pretoria, South Africa: HSRC Publications.

${ }^{16}$ Ibid.

${ }^{17}$ Kenneth Clinton Wheare (1963), Federal Government. Oxford University Press, London.

${ }^{18}$ Robert I. Csehi (2011), supra note 14, see also John Law (2013) How can we define Federalism? Perspectives on Federalism, Vol. 5, issue 3, 2013, ISSN: 2036-5438

${ }^{19}$ Ibid.

${ }^{20}$ Ibid.

${ }^{21}$ For a brief history of the rise of cooperative federalism, see Philip J. Weiser, (2001), 'Towards a Constitutional Architecture for Cooperative Federalism', 79 N.C. L. Rev. 663, 668-73.

${ }^{22}$ Ronald J. Krotoszynski, Jr (2012), 'Cooperative Federalism, The New Formalism, and The Separation of Powers Revisited: Free Enterprise Fund and The Problem of Presidential Oversight of State-Government Officers Enforcing Federal Law', Duke Law Journal, Volume 61, Number 8.

${ }^{23}$ Id. It bases from the puzzles in strictly enforcing separation of power ("denominated formalism") vs. balancing of policy benefits through derogation of assignment of powers 
requires robust institutions and mechanisms with the need to promote intergovernmental relations. Cooperative relations may be conducted both horizontally and vertically; however, a horizontal cooperation does not necessary mean a vertical one. In other words, the constituent units may cooperate without having the same attitude towards the federal level of governance. Competition, on the other hand, means that the different levels of governance, from time to time, challenge one another in the carrying out of policy measures. ${ }^{24}$ The categorization on the form-substance interaction and the form of federalism is based on the policy areas and the political and legal relationship at the different levels of governance. The difference is in the tools used to achieve the end.

As a counter-argument to the cooperative form of federalism, there is "dual federalism" or "dualistic federalism". ${ }^{25}$ It mainly adheres to too "formal approaches" or sticking to "formality" in which this can be taken as its marking feature. ${ }^{26}$ Dual federalism leaves states as distinct and sovereign entities considered as "autonomous actors separated from the federal government". ${ }^{27}$ There are unique competencies among the units. Competition is the main feature of such form among the units. Constituencies may also challenge the federal government. Due to these causes, there are obscure descriptions of the polity in scholarly writings as 'quasi-federal" 28 , as a 'weak federation"29, 'loose federation', ${ }^{30}$, as an instance of 'partial federalism' ${ }^{31}$ and 'federalism without a

to the executive, judiciary and ("denominated functionalism"). The second one stands for the assumptions of cooperative federalism.

${ }^{24}$ Robert I. Csehi (2011), supra note 14.

${ }^{25}$ Philip J. Weiser (2008), 'Federal Common Law, Cooperative Federalism, and the Enforcement of the Telecom Act', New York University Law Review, Vol. 76:1692.

${ }^{26}$ Shannon M. Roesler (2015), 'Federalism and Local Environmental Regulation', University of California, Davis, Vol. 48:1111.

${ }^{27}$ Philip J. Weiser (2008), supra note 25.

${ }^{28}$ John Law (2013), 'How can we define Federalism?' Perspectives on Federalism, Vol. 5, issue 3, 2013, ISSN: 2036-5438.Citing Hueglin Thomas and Fenna Alain, (2006), Comparative Federalism: A Systematic Inquiry, Broadview Press, Peterborough.

${ }^{29}$ Ibid. Citing Moravcsik Andrew (2001), 'European Federalism: Rhetoric and Reality', in NicolaidisKalypso and Howse Robert (eds), The Federal Vision: Legitimacy and Levels of Governance in the United States and the European Union, Oxford University Press, Oxford, 161-87.

${ }^{30}$ Ibid. Citing Wallace William (1996), 'Government without Statehood: The Unstable Equilibrium', in Wallace Helen and Wallace William (eds), Policy-making in the European Union, Oxford University Press, Oxford, 439-60.

${ }^{31}$ Piris Jean-Claude, (2006) 'The European Union: Towards a New Form of Federalism?', in FedtkeJörg and Markesinis Basil (eds), Patterns of Regionalism and Federalism: Lessons for the UK, Hart, Oxford, 69-87. 
federation'. ${ }^{32}$ The extent of autonomy should not thus be absolute or loose; they should rather be considered as autonomous actors but not separated from the federal government and with the duty to create cooperative environment.

Co-operative federalism is one of the pre-requisites to bring legal and policy harmonization in a vertically and horizontally integrated federal structure. Legal harmonization is different from legal unification ${ }^{33}$ because the latter almost seeks to bring sameness while legal harmonization adheres to similarity. ${ }^{34}$ Cooperative or collaborative water governance is defined in different ways. ${ }^{35}$ In one of the round table discussions in Canada, collaborative water governance is defined based on two defining characteristics referring to the "degree of nongovernmental participation, and the degree of delegation of decision-making power". ${ }^{36}$ Adapting Nowlan and Bakker (2007), the approach for collaborative water governance framework ${ }^{37}$ is generally depicted in the context of four forms of governance that are directly relevant to water governance. ${ }^{38}$

Both the consultative and traditional forms of governance have minimal level of delegated decision making. There is extensive participation of nongovernment stakeholders in the consultative form while, on the contrary, participation of such stakeholders is limited in the traditional form. Delegated and multi-level governance forms of governance are different from the preceding two forms because there is significant delegation of decision making to multiple stakeholders including non-governmental stakeholders in the delegated form of governance. It should be clear that the participation of nongovernment stakeholders and the delegation of decision making are vital to cooperation and harmonization by balancing all dimensions.

${ }^{32}$ Id. Bomberg Elizabeth, Peterson John and Stubb Alexander (eds.) (2008), The European Union: How Does It Work? Oxford University Press, Oxford.

${ }^{33}$ See, for example, D. Halberstam and M. Reimann, (eds.) (2014) Federalism and Legal Unification, Ius Gentium: Comparative Perspectives on Law and Justice 28, Springer.

${ }^{34}$ Ibid.

${ }^{35}$ Chris Ansell and Alison Gash (2007) 'Collaborative Governance in Theory and Practice', Journal of Public Administration Research and Theory, Oxford University Press, JPART 18 (2007) pp.543-571 Collaborative governance is defined in different terms. Some of the synonyms include 'corporatism' (signifying tripartite relations), 'associational governance'(formal ones but collaboration may not include the formal ones), 'policy network'( referring to the pluralistic forms of state-society relations but it can be informal and implicit), 'public-private partnership', 'participatory management', 'interactive policy making', 'stakeholder governance', and 'collaborative management'.

${ }^{36}$ NRT on E and E (2011) Charting a Course - Chapter 7: Collaborative Water Governance available at http://nrt-trn.ca/charting-a-course-chapter-7-collaborative-water-governance last accessed January 2018.

${ }^{37}$ L. Nowlan and K. Bakker (2007), Delegating Water Governance: Issues and Challenges in the $B C$ Context, Program on Water Governance. University of British Columbia.

${ }^{38}$ Ibid. 
Collaborative governance becomes meaningful in delegated governance since stakeholders' participation is realistic and entrusts the power of decision making to non-government stakeholders. The empowerment goes beyond consultative governance and minimum delegation, because it involves significant delegation of decision making. Although this is ground breaking to grass root empowerment, the horizontal relations at the grassroots should be harmonized through cooperation among the federating units. The meaning given to collaboration should be extended to inter-local harmonization beyond the collaboration, participation and delegation of governmental and nongovernmental actors and stakeholders. As the extent of delegation in decision making is significant, the difference and incompatibility of water governance systems, practices and functions can negatively affect the efforts of harmonization, integrating governance and preventing and resolving conflicts.

In the context of the functional water governance approach, there should be assessment of whether it is convenient to balance the dimensional interests and themes of water governance. Such governance should also be flexible and responsive for any concurring challenge. The effectiveness of the policy option should be plausible to reconcile empowerment of the grassroots, cooperation of the inter-governmental and local linkages and harmonization of laws, policies and instruments at all levels.

\subsection{Functional approach for dimensional reconciliation and integration}

Water governance can be defined as "the range of political, social, economic and administrative systems that are in place to regulate the development and management of water resources and provision of water services at different levels of society". ${ }^{39}$ The Asian Development Bank group defined water governance as "promoting sound development management" and "the manner in which power is exercised in the management of a country's social and economic resources for development" ${ }^{40}$ Water governance (analogous to the existing definition of land governance) is also defined as the societal arrangements around water, including the structures and processes of authority, collective action, accountability, transparency and participation that both facilitate and constrain improved management. ${ }^{41}$

\footnotetext{
${ }^{39}$ P. Rogers, and A. W. Hall (2003), 'Effective Water Governance', Global Water Partnership, Vol. 7, Stockholm, Sweden.

${ }^{40}$ CDRI (2008) 'Framing research on water resources management and governance in Cambodia: A literature review', Working Paper 37, ISSN 978-99950-52-22-5.

${ }^{41}$ Ibid.
} 
Governance implies management and regulation of the public good that goes beyond the centralized and monolithic nation-state. ${ }^{42}$ Both the development and governance oriented definitions show us similarities in the contents of the elements. There is also "adaptive governance" ${ }^{43}$ In addition to this, water governance is given an equivalent meaning to the rules, structures and powers of management and regulation of water. It is the system that regulates the determination of "who gets what water, when and how, and who has the right to water and related services and their benefits". ${ }^{44}$ The governance dynamics can be affected by plurality of interests; power and politics. ${ }^{45}$ In general, there are different systems and the systems regulate the development and management of water resources in the arrangement of multi-levels of societies. The environmental policy and policymaking experience of Canada, for example, was approached through 'de-regulation' to transit into 'multi-stakeholders policy making' process. ${ }^{46}$

\subsubsection{Water governance dimensions}

Four basic dimensions are identified as important aspects of water governance. First, the social dimension of water focuses on the equity aspect of water access and use. It revolves on issues of equitable distribution of water and services among social and economic groups. Second, there is an economic dimension of water that aims to bring efficiency in water allocation and use. Third, the political dimension focuses on providing equal rights and opportunities to the stakeholders and enabling them to participate in decision-making processes. Fourth, the environmental dimension gives due attention to sustainable use of water and related ecosystem services. These four dimensions show the dynamics, policy and legal framework that are embedded in all the processes and outputs of water resource governance.

${ }^{42}$ Ibid. citing Global Water Partnership (2002)

${ }^{43}$ De Caro, D. et al. (2017), 'Legal and institutional foundations of adaptive environmental governance', Ecology and Society 22(1):32. https://doi.org/10.5751/ES-09036-220132

44 T. Allan (2001), The Middle East Water Question: Hydro politics and the global economy, I. B. Tauris, London and New York.

${ }^{45}$ Maria Jacobson et al (ed.) (2013), User's Guide on Assessing Water Governance, UNDP.

${ }^{46}$ Howlett, M. (2000) 'Beyond legalism: policy ideas, implementation styles and emulationbased convergence in Canadian and U.S. environmental policy'. Journal of Public Policy, 20(3), 305-329. 


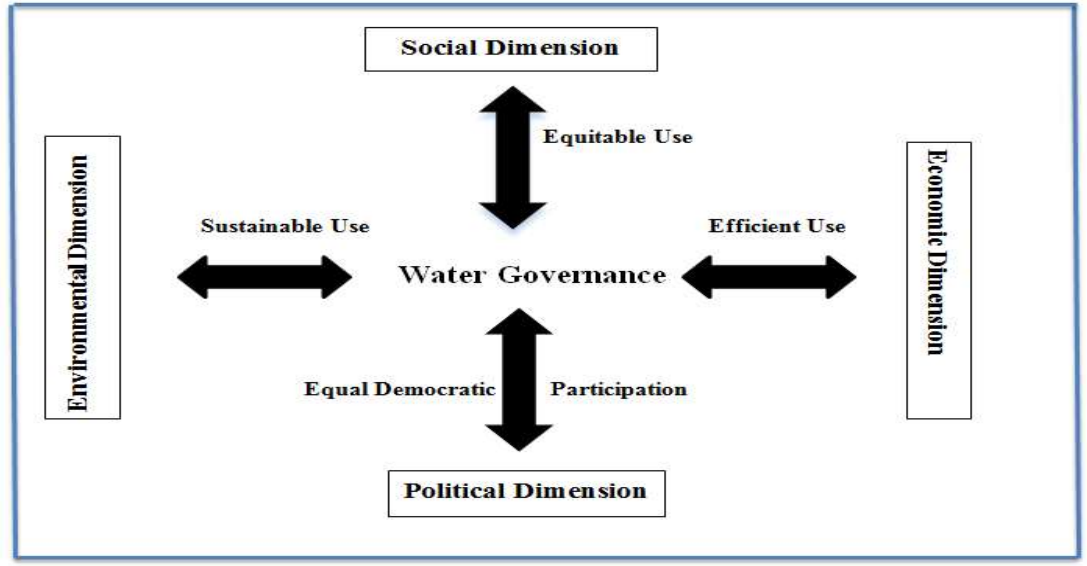

Source: Adapted from Tropp, H., 'Water Governance Challenges', in World Water Assessment Programme, 2006, The United Nations World Water Development Report 2: Water, a shared responsibility, United Nations Educational, Scientific and Cultural Organization (UNESCO ), Paris. ${ }^{47}$

\subsubsection{The water governance and water management nexus}

Water governance and water management are interdependent, but not identical. While water governance is the broader system that sets the rules, structures and authorities, water management is the narrower sphere that deals with the practical tools of management. ${ }^{48}$ An effective governance system is the requirement that facilitates practical tools. ${ }^{49}$ It is clear that both are interdependent. In some literature the term water governance is used interchangeably with integrated water resources management (IWRM) ${ }^{50}$ The UNDP guideline has defined the IWRM as a process that promotes the coordinated development and management of water, with the purpose to maximize economic and social welfare in an equitable manner without compromising the sustainability of the environment.

Most literature classifies issues of water management functions as one category of water governance functions. The management functions refer to standard activities expected to be performed by sector institutions and examples of such activities include planning, allocation, service delivery and conflict mediation, among many others. ${ }^{51}$ Any assessment on water governance will be

\footnotetext{
${ }^{47}$ Cited in Maria Jacobson et al. (ed.) (2013), supra note 45.

${ }^{48}$ Maria Jacobson et al. (ed.) (2013), supra note 45.

${ }^{49}$ Cecilia Tortajada (2010), 'Water Governance: Some critical issues', International Journal of Water Resources Development, Vol. 26, No. 2, pp. 297-307.

${ }^{50}$ Maria Jacobson et al. (ed.) (2013), supra note 45.

${ }^{51}$ Ibid.
} 
approached through the entry points of water management functions. For instance, the impact, outcome, and impact of decentralization will be seen through the disaggregation of manageable elements of management functions accommodating dynamism. ${ }^{52}$ Regulatory functions may also be seen as management functions and the regulatory functions can have other subset functions such as water resource allocation. The regulatory function involves the enforcement of controls and restrictions on water use, allocation and management. This requires the enforcement of laws and policies through responsible public bodies. Specific issues include regulating the volume of water extraction, issuance of water permits, control of pollution and others.

\subsubsection{IWRM and IRBM: Synthesis of performance indicators}

Integrated Water Resource Management (IWRM) is an emerging approach to water resources governance. The 1992 UN Conference on Environment and Development (Earth Summit, Rio de Janeiro) underlined what IWRM is under its Agenda 21. Primarily, it requires the integration of land and water aspects. Second, the integration is carried out at catchment basin or sub-basin level. The central question should be on what is to be integrated, for what purpose, and why it is required at hand. Third, the summit has underlined the pursuit of four principal objectives:

(a) To promote a dynamic, interactive, iterative and multisectoral approach to water resources management, including the identification and protection of potential sources of freshwater supply, that integrates technological, socio-economic, environmental and human health considerations;

(b) To plan for the sustainable and rational utilization, protection, conservation and management of water resources based on community needs and priorities within the framework of national economic development policy;

(c) To design, implement and evaluate projects and programs that are both economically efficient and socially appropriate within clearly defined strategies, based on an approach of full public participation, including that of women, youth, indigenous people and local communities in water management policy-making and decision-making;

(d) To identify and strengthen or develop, as required, in particular in developing countries, the appropriate institutional, legal and financial mechanisms to ensure that water policy and its implementation are a catalyst for sustainable social progress and economic growth.

\footnotetext{
52 Jose Esteban Castro (1995), 'Decentralization and Modernization in Mexico: The Management of Water Services', Natural Resources Journal, Vol. 35, No. 3, pp. 461-487.
} 
The Global Water Partnership has defined IWRM as “... a process which promotes the co-ordinated development and management of water..." to maximize dimensional welfares without compromising sustainability. ${ }^{53}$ It is defined as "... co-ordinated control, direction or influence of all human activities in a defined environmental system to achieve and balance the broadest possible range of short-and long-term objectives. ${ }^{54}$ In general, it is defined as an approach, process, activity, direction, objective etc., to bring cross-sectoral collaboration and coordination in decision making process through participatory and adaptive approach.

The task of conceptualizing and operationalizing IWRM is currently reduced to its subset and deals with the implementation of IRBM at a basin scale. There are certain building blocks of the IRBM. It is a systematic (inter-relationship among human and natural systems), strategic (key issues or variables and their linkages), participatory (governments, citizens, and non-government groups), and balanced (economic development, ecosystem protection and social values and norms) approach. ${ }^{55}$ Others also define it as a tool for effective IWRM and water governance free of governance crises. ${ }^{56}$ Watershed management is characterized holding of dimensional complex problems. ${ }^{57}$ The need to look outside the box for new concepts or adaptive approaches is necessary in managing a basin through the collaboration of local watersheds. There are various IRBM principles which call for: ${ }^{58}$

[e]ngagement of and ownership by relevant decision-makers, improved river basin management design, application of diverse institutional arrangements, clear definition of the role and structure of the river basin organization (RBO), strong river basin advocacy, prioritizing actions, accountability, local

${ }^{53}$ Bruce P. Hooper (2006), Key Performance Indicators of River Basin Organizations, 2006VSP-01, available at <https://www.iwr.usace.army.mil > last accessed on March 15, 2019. See also Global Water Partnership Technical Advisory Committee. (2000) Integrated Water Resources Management, TEC Paper No. 4, Stockholm, Global Water Partnership.

${ }^{54}$ Ibid. Citing S. M. Born \& W. C. Sonzogni (1995), 'Integrated environmental management: strengthening the conceptualization', Environmental Management 19[2], 167-181. Citing Cairns, (1991)

${ }^{55}$ Ibid. Citing B. Mitchell \& M. Hollick (1993), 'Integrated Catchment Management in Western Australia - Transition from Concept to Implementation', Environmental Management 17[6], 737-743,

${ }^{56}$ Ibid. This recognition is illustrated in an agreement reached at the $3^{\text {rd }}$ World Water Forum in Kyoto, Japan. "the key is...We face a governance crisis, rather than a water crisis. Water governance is about putting IWRM with river and lake basin management and public participation as critically important elements, into practice."

${ }^{57}$ Ibid. Citing R. J. Naiman (1992), Watershed Management: Balancing Sustainability and Environmental Change, New York, Springer-Verlag.

${ }^{58}$ Ibid. 
Government partnerships for effective implementation, and integrating functions for collaboration respectively .

The principles may be used as performance indicators or additional indicators may be developed. The most common indicators include coordinated decision-making addressing the links between local water institutions, responsive decision making, ${ }^{59}$ goals, goal shift and goal competition, financial sustainability, organization design, role of law, training and capacity building, information and research, accountability and monitoring and private and public sector roles. Moreover, coordinated decision-making process, ${ }^{60}$ organization design, and the existence of laws that support river basin management laws (characterized by strong and flexible arrangements) are very important in this regard. To this end, legislation is expected to specify the functions, structure, financial base and accountability mechanisms in river management.

The form and nature of river basin organizations may vary. They may be established as advisory committee, authority, association, commission, council, corporation, tribunal, trust, or federations. Each type may have variation in the scope and nature of its powers, duties, institutional design and general structure. In general, the overall defining elements of IWRM and IRBM are in tandem with the cooperative form of federalism, and the dimensions of water governance are related to issues of water management.

\subsection{Governance approaches in inter-governmental and inter-local linkages}

Inter-governmental relation is a link at different levels of government where a decentralized system of governance is adopted. Decentralization necessarily redefines the relation between different levels of government. The intergovernmental or inter-local linkages within a decentralized form of governance are also fostered by the type of governance approach embedded to facilitate the integration of interventions and issues of management.

The bottom-up concept can be defined as "progressing from small or subordinate units to larger or more important units, as in an organization or process". ${ }^{61}$ It engages the network of actors, involved in service delivery, in

${ }^{59}$ Ibid. A decision processes which adapt to new knowledge and new conditions; promote efficiency; value cross-sectorial dialogue; promote best practices.

${ }^{60}$ Ibid. Existence of quality control mechanisms to avoid bias in monitoring, planning and management through coordination of a range of state, federal, commercial and private NGO bodies. Evidence of coordination mechanisms to enact integrated management and use of multiple agency approach with overarching coordination body.

${ }^{61}$ American Heritage ${ }^{\circledR}$ (2016) Dictionary of the English Language, Fifth Edition available at $<$ https://www.amazon.com>. Last accessed on December 17, 2017 
different localities by identifying their goals, strategies, activities and contacts ${ }^{62}$ in order to develop networking, harmony and synergy. This can also be applied in water governance. ${ }^{63}$ The Dublin statement on water and development guides a participatory approach with the involvement of "... users, planners and policy makers at all levels". ${ }^{64}$ It implicitly states that "... decisions are taken at the lowest appropriate level, with full public consultation and involvement of users in the planning and implementation of water projects." ${ }^{\prime 25}$

On the contrary, the top-down policy approach is seen in terms of legal and political variables. ${ }^{66}$ It is to be noted that the history of water governance has also been centralized and characterized by top-down decision making. The topdown approach usually prioritizes centralized regulation and clear policies. ${ }^{67}$ It tends to consider statute framers as key actors and disregards other key stakeholders. ${ }^{68}$ However, general policy frameworks may help to avoid variations among the states. ${ }^{69}$ Substantial variations across states in terms of the ability to maintain the commitment to environmental protection in Canada and the United States were, for example, characterized in four categories as progressives, strugglers, delayers and regressives. ${ }^{70}$

The first task in water governance should be assuring harmonization and avoiding fragmented divergence that adversely affect stable institutions. The creation of stable institutions also helps to foster-up the linkage and partnerships for cooperative environment. The inter-governmental relations on water need to

${ }^{62} \mathrm{~K}$. Hanf et al. (1978), 'Local networks of manpower training in the Federal Republic of Germany and Sweden', in K. Hanf and F. Scharpf (eds), Inter-organizational Policy Making: Limits to Coordination and Central Control, London: Sage, pp. 303-344.

${ }^{63}$ Lucie Cerna (2013) The Nature of Policy Change and Implementation: A Review of Different Theoretical Approaches, OECD, available at www.oecd.org last accessed on January 20, 2018

${ }^{64}$ Ibid.

${ }^{65}$ Ibid.

${ }^{66}$ P. Sabatier (2005), 'From policy implementation to policy change: a personal odyssey', in A. Gornitzka, M. Kogan and A. Amaral (eds), Reform and change in higher education: analyzing policy implementation, Dordrecht: Springer, pp. 17-34.

${ }^{67}$ R. Matland (1995) 'Synthesizing the implementation literature: the ambiguity-conflict model of policy implementation', Journal of Public Administration Research and Theory 5(2): 145-174.

${ }^{68}$ Ibid.

${ }^{69}$ See for example, Ahmed Shafiqul Huque \& Nathan Watton (2010), 'Federalism and the Implementation of Environmental Policy: Changing Trends in Canada and the United States', Public Organize Rev, 10:71-88.

${ }^{70}$ Ibid. 
be implemented through local institutions. Comparative experience shows the need for stable institutions. As stated in AWBA's report: ${ }^{71}$

Existence of stable institutions is indispensable to enhancement of linkages and partnership among stakeholders for the realization of efficient, sustainable and equitable water resources management. Several federal and regional institutions have been established to implement integrated water resources management. However, the institutions' structure lacks appropriate linkage, institutional stability and flexibility to increase participation of stakeholders.

This is a clear statement indicating on how the lack of appropriate institutions may impede the linkages at higher and lower levels. The mere establishment of institutions at Federal and regional levels may not facilitate integration and partnerships towards better realization of the dimensional interests. Institutions that integrate inter-governmental relations need to be supported by local water institutions with the objectives of effective participation, empowerment, integration, cooperation and harmonization.

This may include national-local, state-local, national-state-local, and interlocal relations beyond national-state and interstate relations. ${ }^{72}$ In general, it should be understood as "interactions occurring between governmental units of all types and levels" ${ }^{\prime 3}$ in the context of holistic stakeholder engagement. The quality of the governance approach should also be assessed on all types and levels of relations.

\section{Water Resources Policy Framework}

The nomenclature 'Ethiopian Water Resources Management Policy' makes reference to the 'management' rather than the governance aspect. As indicated earlier, there is a conceptual difference between governance and management aspects of water ${ }^{74}$ because the governance aspect is broader than management issues. It deals with the processes and institutions while management is a particular task or the practical implementation or functioning through the tools. While issues of governance come before decisions, issues of management follow decisions. Unlike its title, however, the policy document broadly embodies water governance issues. For instance, it discusses assuring enabling environment to issues of water management. The policy considers the need for

\footnotetext{
${ }^{71}$ Awash Basin Authority (2017), supra note 3, p, 46

${ }^{72}$ DS Wright (1975), 'Intergovernmental Relations and Policy Choice'. Publius 5 (4): 1-24.

${ }^{73}$ Anderson W. (1960) Intergovernmental Relations in Review. Minneapolis: University of Minnesota Press.

${ }^{74}$ Maria Jacobson et al (ed.) (2013), supra note 45.
} 
institutional frameworks as an enabling environment to the management efforts under each sector of water use type and services.

The Policy states that the management of water supply systems should be ensured at the lowest and most efficient level of institutional set up. This is meant to provide ".. the full participation of users and to promote effective decision making at the lowest practical level." The key term 'management' is used interchangeably including the governance aspect of water. Issues of participation and decision making processes mutually refer to governance issues of water management. The policy statement calls for bottom-up governance with regard to the need of institutional frameworks and stakeholders in drinking water supply. ${ }^{75}$ Defining the roles of the institutions and stakeholders at all levels "including Federal, Regional governments, ESAs, NGOs, private sector, etc" is also stated as a direction under Section 4.1(5) of the Water Policy.

The National Water Strategy (NWS) adds some qualifying strategies on how to realize the direction of the overall policy. The NWS states four fundamental and guiding principles with regard to the formulation of national water strategy. It is stated that the principles for the strategy emerged from the policy statements. The first and fourth guiding principles have relevance to this discussion. First, it recalls the ownership issues stated under the Constitution that water is "....a natural endowment commonly owned by all the people of Ethiopia." It avoids the ethnic and nationality elements attached to the definition of land ownership stated under the Constitution. Second, any issue of water resources development is required to be "rural-centred" that pursues "decentralized management, participatory approach as well as integrated framework." The decentralization relates to management issues of water resources development, and the strict reading of the terms implies that the policy does not adhere to bottom-up governance. As most issues are addressed in the policy, it is difficult to expect some critical policy formulations at the lower or local level; and the general framework is imposed from the top. ${ }^{76}$

However, it can be argued that the policy has used a mix of different elements that do not support each other. Although the title of the policy refers to management issues, the content, more or less, refers to governance issues. The holistic reading of the policy and strategy show that governance issues of water management aspects are addressed. Yet, decentralized 'water resources development' conducted in participatory approach does not make sense without corresponding decentralization and grassroots empowerment in decision making

\footnotetext{
${ }^{75}$ FDRE Water Policy (1997), p, xxi

${ }^{76}$ Elizabeth A. Koebele (2015), 'Assessing Outputs, Outcomes, and Barriers in Collaborative Water Governance: A Case Study', Universities Council on Water Resources, Journal of Contemporary Water Research \&Education, Issue 155, pp. 63-72.
} 
and the institutionalization process. Lessons can, for example, be drawn from U.S experience on decentralization of environmental powers. ${ }^{77}$

\subsection{Participatory approach and grassroots empowerment:}

Under the introduction part of the policy document, it is stated that the policy on management is in line with FDRE Constitution's Macroeconomic and Social policies, objectives and development strategies. Most importantly, it recalls that an in-depth and enriched discussion was made at the grassroots ${ }^{78}$ "in consideration of the inclusion of all felt needs and mutual interests of all the peoples of Ethiopia" and it states that "the policy was discussed in depth and enriched at the grassroots level with representative participants from all Regional States up to Wereda level and relevant bureaus." The phrase "inclusion of all felt needs' recalls that a national need assessment was made and this could help to identify the mutual interests of the people.

However, there are two critical issues that evoke concern. First, the participation was done up to Wereda level. The scale and level of selecting participants with reasonable size may be questioned. The lowest level or unit of administration is designed in the Kebele or Tabia representing the smallest unit of government, and the link between citizens and the government is practised at this level. Second, the form of participation is through representation, and not through direct participation of stakeholders. The policymaking processes may thus be questioned in terms of the participants and the nature and degree of interests accommodated in the policy documents. This can be seen and checked with other research findings on the area to cross-check whether there was comprehensive and valid process to accommodate current needs and interests.

\subsection{Manifestations of co-operative federalism and inputs for legal harmonization in local-local linkages}

The policy document identifies some crosscutting issues which, inter alia, include the institutional framework. The policy underlines that the need for institutionalization of water management as a priority. ${ }^{79}$ Moreover, the promotion of "... appropriate linkage mechanisms for the coordination of water resources management activities between the Federal and Regional Governments" is addressed. First, the policy impliedly recognizes the potential difference in water management activities between the federal and regional

\footnotetext{
${ }^{77}$ Ahmed Shafiqul Huque \& Nathan Watton (2010) supra note 69.

${ }^{78}$ FDRE Water Policy (1997), p, iv.

${ }^{79}$ C. Sneddon (2002), 'Water Conflicts and River Basins: The Contradictions of Comanagement and Scale in Northeast Thailand', Society and Natural Resources 15: 725 741.
} 
governments. Second, it indicates that 'appropriate linkage' should be created between actors and activities existing in the federal setting.

Third, it requires linkage mechanisms as additive inputs to co-ordination mechanisms. The 'co-ordination' as one element of the federal-regional, regional-regional, or local-local settings is crucial in avoiding asymmetrical regulations and practices. This impliedly shows the need to have coordinating institutions of such linkages. According to the fourth principle, water management for water resources development shall be 'rural-centred', pursue 'decentralized management', and 'adhere to participatory approach and integrated framework'.

The decentralization and integration aspects of water governance directly represent water federalism. The balance between these aspects requires cooperation and coordination for legal harmonization in local-local linkages among federating units. ${ }^{80} \mathrm{~A}$ survey in India reveals on how to "unleash dynamism" in this regard. The main argument is to shift from competitive federalism to sub-competitive federalism. ${ }^{81}$ However, this has to be harmonized in the context of cooperation by reconciling the competence and interests of the empowered units at the grass roots.

'Appropriate institutional frameworks' at the lowest administrative structure in a local setting require 'decentralized management' and the 'participation of user communities' ${ }^{82}$ This envisages the shared and self-rule arrangement of water management issues in a federal arrangement. As there is more decentralization of power, there should be an initiative of bringing harmonization through cooperation of actors and duties of coordination. This is a typical example in cooperative federalism. A strategy is adopted to encourage 'relevant stakeholders' to engage in 'joint management' of basin authorities. Although this resembles the experience of environmental federalism ${ }^{83}$ adopted during the 1960s in the U.S, such 'conjoint federalism' gives central and federating units the power to administer environmental issues conjointly. With regard to the Ethiopian case, however, there is the need for clarity regarding the actors' that are considered as 'relevant stakeholders'; and joint management needs to be clearly defined.

\footnotetext{
${ }^{80}$ P. Wandschneider (1984) 'Managing River Basin Systems: Centralization versus Decentralization', Natural Resources Journal 24(4): pp. 1042-1066.

${ }^{81}$ Economic Survey (2016-17), 'From Competitive Federalism to Competitive SubFederalism: Cities as Dynamos', Chapter 14, 302 Economic Survey 2016-17 available at $<$ https://www.indiabudget.gov> Last accessed on January 2018.

${ }^{82}$ Philip J. Weiser (2008), supra note 25.

${ }^{83}$ Ahmed Shafiqul Huque \& Nathan Watton (2010) supra note 69
} 
The strategy document further includes detail strategies on how to create enabling environment or 'effective institutions' and secure sound institutional basis aiming to bring sustainable development and management of water resources. They are considered as short term implementation of such activities. ${ }^{84}$ It envisages the establishment of appropriate and effective river basin management institutions, autonomous or semi-autonomous utility agencies or companies in big towns. It also encourages 'local artisans' and the private sector to establish association for proper and sustainable organization and management activities. It indicates the need to promote the creation of Water Users Association (WUA) and Irrigation Agencies, where appropriate.

The fifth feature of the policy document relates to its encouragement towards the establishment of water committees at wereda, zonal, kebele and water scheme levels. To this end, it aims at decentralizing water services, to the extent possible, to financially autonomous utilities and institutions, which may be public corporations, private firms, co-operatives or user groups. For example, U.S experience in environmental policies shows corporatization whereby environmental mitigation activities were marketized or given to the private sector. ${ }^{85}$

\section{FDRE Water Management Proclamation No. 197/2000 and Regional State Laws: Some Observations}

Article 2(19) of the FDRE Water Management Proclamation 197/2000 defines water management as an exhaustive set of activities including activities of water resources development, utilization, conservation, protection and control. The fifth element has direct relevance to water governance issues. The principle of water management decentralization stated under the policy is not embodied the Proclamation. The power of water management is given to the 'supervising body'. Although the 'supervisory authority' is, in principle, the Ministry of Water, Irrigation and Energy at the central level of the federal structure, it can be any organ that can be delegated by the Ministry. The delegation is expected to be pursuant to Art 8(2) of the Proclamation. This provision also states the powers and duties of the supervising body.

There are two important conditions to be observed in the course of delegation. First, delegation is possible where it is necessary. Second, the delegation will be to appropriate organs that can execute the task efficiently. Delegation of power is different from decentralization.

\footnotetext{
${ }^{84}$ Under the strategy document, short term is meant for 2 or 3 years.

${ }^{85}$ Ahmed Shafiqul Huque \& Nathan Watton (2010) supra note 69.
} 
The FDRE Constitution ${ }^{86}$ entrusts regional states with the power to administer land and other natural resources found within their territory in accordance with the federal laws. The issue of delegation of power to manage water to respective states seems to be inconsistent with the power exercised within their boundary. Clarity should thus be added because explicit definition is necessary on what water management and water administration constitutes under the Constitution. Although the registration, recording and dissemination of water uses and discharges may be considered as main activities of water administration, these powers are also given to the Supervising body. ${ }^{87}$

The room for promoting participatory approach in line with the direction of the policy is not embodied in the Proclamation in which the participation and consultation forums involve 'concerned public bodies', but not communities or civil societies. ${ }^{88}$ This is a gear shift from the objectives, principles and aspiration of the policy and strategies. The legal framework does not empower local actors at the grassroots. ${ }^{89}$ The relevant laws of Tigray, Amhara, Oromia and Afar regional states are highlighted below to examine the status of decentralized powers and duties, and the legal empowerment in relation to their degree of harmony among their laws. The discussion further examines the issues of cooperation and bring functional governance in light of the federal water basin laws.

Tigray Regional State Water Irrigation Infrastructure Development, Utilization and Administration Proclamation $258 / 2015^{90}$ is one of the specific laws on water issues in Ethiopia. The law is promulgated in with Art 49(3) of the Regional Constitution. This particular provision states the Regional State's power to enact specific laws without contradicting the FDRE Constitution. The

${ }^{86}$ Power of the States under Art 52(2):

(c) "To formulate and execute economic, social and development policies, strategies and plans of the State;"

(d) "To administer land and other natural resources in accordance with Federal laws;

Power of the federal government under Art. 51(11):

"It shall determine and administer the utilization of the waters or rivers and lakes linking two or more States or crossing the boundaries of the national territorial jurisdiction."

Power of HPR under Article 55(a):

"Utilization of land and other natural resources, of rivers and lakes crossing the boundaries of the national territorial jurisdiction or linking two or more States"

${ }^{87}$ Art 10, Inventory of Water Resources and Registry of Water Actions.

${ }^{88}$ See for example Chris Ansell and Alison Gash (2007), supra note 35

${ }^{89}$ See for example, Suzanne von der Porten and Robert C. de Loë (2013) 'Collaborative approaches to governance for water and Indigenous peoples: A case study from British Columbia', Canada, Geoforum 50, p, 153.

${ }^{90}$ Title translated by the author. 
scope of the Proclamation's application (under Article 4) covers any water irrigation or dam constructed by the budget of the regional state, the society, investor, NGO or the Federal government but in which the power of management and administration is transferred to the Regional State. The main purpose of the Proclamation is to bring sustainable, effective, and equitable utilization of water under the existing institutions (Art 5/1). Maintaining sustainability, avoiding unregulated schemes (Art 5/6) and challenges in water utilization and administration are also among the Proclamation's purposes (Art $5 / 5$ ). With regard to participation, it aims at empowering women and involving them in decision making participations (Art 5/7).

The fifth part addresses issues of water governance. The Tigrigna word 'Mihdera' is closer to the meaning equivalent to governance than 'Astedader' which may be ambiguously interpreted as administration, management, or governance. The Bureau will follow-up, put directions of water utilization to water users, give approval for the tools, methods, manners, time and place of water utilizations. This indicates overall supervision by the bureau while the details will be determined by the water users. The sixth part of the Proclamation (which starts from Article 53) explains the level of social participation in aspects of water governance. Most of the issues are almost exhaustively addressed in the provisions which state that the highest level of participation of the societies and communities is required (Art 33/1). Although the right to highest participation makes express reference to water users, this does not exclude the participation of other counterparts. Article 33(3) of the Proclamation gives the autonomy of water governance to local administrations, local institutions, and committees. The Proclamation allows them to prepare by-laws and it aspires to create sense of belongingness.

The by-laws are approved by the Bureau which also has the duty to check whether the by-laws are consistent with the Proclamation (Art 34/i). As stipulated under Article 34, the tasks of the Bureau include giving technical support, providing trainings to create awareness, support to form an association, oversight on the association's book of account, taking part in institutionalization process, and follow-up measures. It also has the power to evaluate the committees as a form of joint participation and to scale up best experiences of a locality to similar other localities (Art 34/L). Except for disputes arising from the extraction of water from closely located water wells, Article 35(b) of the Proclamation gives autonomy and empowers the associations to establish a committee for complaint handling and dispute resolution comprised of five minimum members. Any aggrieved party has the right to appeal to formal courts after exhausting the remedies (Art 35/E). Giving autonomy to dissolve disputes at local committee levels promotes the participatory approach, empowerment, and it brings sustainable, equitable, and efficient water governance system thereby partially facilitating bottom-up water governance system. 
Amhara National Regional State Executive Organs Re-Establishment and Determination of their Powers and Duties Proclamation No 176/2010 states that Bureau of Water resource Development of the regional state is re-established. Pursuant to Article 19(17) of the Proclamation, the Bureau has the power to "[p]repare and distribute the Region wide draft water resource management policy, laws, regulations, directives, strategic plans, standards and working manuals as well as follow up and oversee their implementation thereof."

Oromia Regional State Irrigation Development Authority Establishment Proclamation No 30/1999 defines irrigation development as the construction of river diversions, dams, farm structure and other related irrigation construction related works (Art 2/5). The Authority is established with the objective of enabling the community to participate in the study, construction, administration of irrigation projects and benefit from them among other objectives (Art 4/3). Similar to Amhara Regional State, the Authority is given the power to initiate and submit policies, strategies, laws and regulations (related to its functions) to the executive committee and implement the same upon approval. This raises the question of compatibility with Federal laws especially in river basins that may have substantial impact to the river basins administered by the Federal authorities.

In general, the regional laws embody governance functions, laws, policies, strategies and practices in the horizontal and vertical relations of water governance. The top-down approach for harmonizing the rules of the game and the practices by establishing water authorities may not facilitate functional governance approaches. The grassroots should be empowered with the purpose of facilitating consensus on how the governance may be functional by creating the norm of cooperation and belongingness.

The preamble of Afar Rural Land Administration and Use Proclamation ${ }^{91}$ states that the law is necessitated by the decentralization of the power to administer land and related resources under the FDRE Constitution and the Rural Land Administration and Use Proclamation's empowerment of regional states to legislate their own related laws based on their contexts. ${ }^{92}$ Article 20(1) of the Afar Rural Land Administration and Use Proclamation states the need for preparing rural land use plans and it underlines that a watershed approach should be adhered.

Article 21 of the Afar Rural Land Administration and Use Proclamation states the responsibilities of the authorities. The Authority has the duty of

\footnotetext{
${ }^{91}$ Afar National Regional State Rural Land Administration and Use Proclamation No. 49/2009.

${ }^{92}$ Federal Rural Land Administration and Use Proclamation No. 456/2005, Article 17(1).
} 
establishing and strengthening rural land administration institutions (Art 21/1) including water administration institutions. It also has the duty to cooperate and collaborate with relevant institutions by giving technical and other related trainings to implement the Proclamation. According to Article 21(4) of the Proclamation, "[t] he authority shall be responsible to lay a system that enables the exchange of information on rural land administration and use between federal [organs] and the Region; and also between the Woredas in the Region." The exchange of information is expected to be made between the federal and regional government and also between Woreda administrations of the region. Although this is a good example of coordination, the statement relating to the establishment of the committees does not specify water administration and it descends from the top administration.

\section{The Institutional Framework: River Basin High Councils and Authorities}

\subsection{Promoting Integrated Water Resources Management (IWRM)}

Lessons can be drawn from comparative experience in promoting IWRM and IRBM under a federal state structure. The Murray-Darling Basin of Australia is one of the most cited cases and the institutional arrangement of the basin has evolved through three stages. First, it was preceded by inter-governmental agreement on allocation of water for three states, then scope and structure of the inter-governmental arrangement was extended and finally integrated water resource management emerged with new organizational structures and relationships at sub-basin and basin levels. Financial support was given from both the national and state governments. Australia's experience shows that it is mandatory to bring cooperation and coordination for harmonized and reconciled interventions.

In 2009, the Global Water Partnership had prepared a handbook on IWRM in basins. ${ }^{93}$ The document states that IWRM is an approach that coordinates the management aspects, sectors and interests groups at different scales. It addresses the need for involvement in national policy and law-making processes, establishment of good governance, and the creation of effective institutional and regulatory arrangements as a route to equitable and sustainable decisions. In applying this approach, a range of tools including social and environmental assessments, economic instruments, and information and monitoring systems support the process. ${ }^{94}$

${ }^{93}$ Global Water Partnership (GWP) and the International Network of Basin Organizations (INBO). (2009), A Handbook for Integrated Water Resources Management in Basins, available at $<$ www.gwpforum.org $>$. Last accessed on Sept 15, 2019.

94 Ibid. 
The management of the integration task is facilitated by the establishment of 'Basin organizations', which according to the Handbook, can be formal or informal, large or small. The purpose and function of such organizations may vary in accordance with factors such as mandates. ${ }^{95}$

As stated under the second and third paragraphs of the preamble of FDRE Water Policy (1997), the major aim of establishing river basin councils and authorities is implementing the integrated water resources management which may need arrangements to reconcile different types of uses in the river basin settings. There is no clear stipulation on the type of governance approach is adopted in the Proclamation. Introducing river basin councils and authorities primarily aims at contributing significantly to the creation of efficient and stable mechanisms for the implementation of the policy. The fifth paragraph of the preamble notes the need for "....river basin plans and effective sustainable joint management by relevant stakeholders of the water resources of the basins."

This statement shows the relevance of stakeholders' involvement and the nature of 'joint-management'. Due to the integrated nature of the management process, the stakeholders, as stated in the fourth paragraph of the preamble, are expected to act in a coordinated manner "... in spite of their differences of approaches, interests and perceptions of the effects of their decisions, plans and activities on the hydrological cycle and on other users." The principle of coordination is laid in the efforts of the stakeholders. This also results in compromises of differences in approaches, interests, and attitudes on decisions, plans and uses leading to uniformity through joint management approaches. This is a good example for harmonization of differences through cooperation and coordination. ${ }^{96}$

However, the River Basin Councils and Authorities Proclamation No. $534 / 2007$ seems to have aspired unification beyond harmonization. Such patterns may be favourable to the integration, but it can be a serious cause for disuse and ignorance of local knowledge, innovation and experimentation for overarching policy frames. ${ }^{97}$ There should thus a balance which is not strictly tight or widely loose. The type of management envisaged under the Proclamation is qualified as effective and sustainable 'joint-management' and the actors are referred to as the 'relevant stakeholders'. This requires further clarity by defining effective and sustainable joint-management. The central factor which is helpful to define the participatory approach of governance is

\footnotetext{
95 Ibid.

${ }^{96}$ See for example, S. Michaels et al. (2010), 'Challenges of Collaborative Water Related Decision-Making.' Briefing Note \#2, Water Policy and Governance Group, University of Waterloo, p. 1.

${ }^{97}$ Philip J. Weiser (2008), supra note 25.
} 
identification of the relevant stakeholders. Article 2(3) of the Proclamation defines a stakeholder as “... any person who is deliberately or unintentionally involved in; or directly or indirectly affected by, water resources management in a basin." It is a broader and inclusive definition that can include all potential actors at the grassroots. This can bring grassroots empowerment through the participatory approach. However, the type of governance approach which is adhered on the ground will determine the degree for empowerment without neglecting harmonization.

The members of the High Council are expected to be designated by the government (Art 5/1) without direct representation from the large public. Active participation of the stakeholders is not sought under the law, and the executive branch will assign the members of the High Council. They are made accountable to the Council of Ministers under the relevant regulation. Their power is broader and is inconsistent with the main rationales stated in the preamble of the Proclamation.

Article 9(1-4) of Proclamation No. 534/2007 states the powers and duties of the Basin Authority which serves as the secretariat of the river basin councils. It has the power to initiate and submit policy measures on IWRM to the councils and follow up of their implementation; facilitate their implementation; ensure the consistency of any intervention with the IWRM processes; prepare a basin's plan and submit to the Council and follow its implementation; issue permits (as long as it does not affect the power given to the regional state by the law) and follow up their compliance; collect and disseminate information as an input for planning, administration and other tasks; develop and use a river basin model to guide strategic planning and water administration functions; give dispute resolution advice and technical support to the Councils or the Ministry pertaining to issues of water use and allocation; create a forum for effective networking among stakeholders; and other activities that are helpful to meet its objectives.

Basin Authorities are accountable to the High Councils with regard to the powers given to the Councils (Art 10/1). With regard to the powers falling under their jurisdiction, Basin Authorities are accountable to the Ministry (Art 10/2), currently the Ministry of Water, Irrigation and Energy. However, the the recent regulation for the establishment of Basin Development Authority by a new directive integrates and centralizes the functions of the designated river basin councils and authorities. ${ }^{98}$ The authority is already established and some reforms are also in a making.

\footnotetext{
${ }^{98}$ This Regulation is issued based on Articles 5 and 34 of the Definition of Powers and Duties of the Executive Organs of the Federal Democratic Republic of Ethiopia Proclamation No. 1097/2018
} 
The other central issue is the duty to cooperate with the River Basin Authority with regard to the implementation of the Proclamation as stipulated under Article 19 of the River Basin Councils and Authorities Proclamation No.534/2007. However, accountability to the River Basin Councils should also have been stated because the power to manage water use disputes of regional states is (pursuant to Article 6/6) the power of the Basin High Councils.

The Proclamation states the reasons for the establishment of river basin councils and basin authorities. The first reason is the uneven distribution of water resource in time and space, an increase in economic growth resulting in an increase in the demand of water and the correlative impact on the quantity and quality and the need for managing such adverse effects. As indicated in the second paragraph of the Proclamation's preamble river basin councils and authorities are considered as "main instruments to implement integrated water resources management" which constitutes "the pillar of the policy". This, as stated in the third preamble of the Proclamation, requires "balance and sustainable development of water resources within a river basin ... as economic as well as environmental resources".

The integration requires the coordination of the stakeholders of a river basin (envisaged in the fourth preamble of the Proclamation) despite the existing differences in approaches, interests, and perceptions in effects of the decisions, plans, and activities on the hydrological cycle and other users. The councils and authorities are also sought to have significant contributions “... in creating efficient and stable mechanisms for the implementation of the Ethiopian Water Resources Management Policy through river basin plans and effective and sustainable joint management by relevant stakeholders of the water resources of the basins." However, the preamble does not expressly state the purpose of establishing the councils and authorities in relation to the avoidance of interregional conflict on water resources even though this issue is indicated under the power and duties of the councils. ${ }^{99}$

Although the Proclamation provides for the establishment of River Basin High Councils and Authorities, there is no regulation issued by the Council of Ministers based on Article 3(1) of the Proclamation. Article 3(2) of the Proclamation envisages that two or more river basins, where it deems necessary, might be put under the jurisdiction of a single Basin High Council and Authority. The overall objective of establishing such organizations is to promote and monitor the integrated water resources management process in the river

${ }^{99}$ Young-Doo Wang, et al. (2000), 'Enhancing Sustainability in River Basin Management through Conflict Resolution: Comparative Analysis from the U.S and South Korea', Chapter 11, Water: A Source of Conflict or Cooperation? 
basins under their jurisdictions. This is in line with the objective enshrined in Article 4 of the Proclamation to use “...the basins' water resources for the socio-economic welfare of the people in an equitable and participatory manner, and without compromising the sustainability of the aquatic ecosystems."

The authorities are required to facilitate the implementation of basin's integrated water resources management as defined in Article 2(4) of the Proclamation. They should ensure the compatibility in content, schedule, impacts and management between the projects, activities and interventions with the process of integrated water resources management. They have the mandate to prepare and submit the basin's plan to the Basin High Council and monitor the implementations upon approval. They are also given the power, but without prejudice to each regional state's power given by law, to issue permits applicable to the basin's water use and water works in line with Article 15 of the Proclamation governing the issue. Moreover, they are given the power to ensure that the terms of the permits are respected by the users.

Three river basin high councils and authorities, i.e., the Awash Basin High Council and Authority, Abbay Basin High Council and Authority and Rift Valley Lakes High Council and Authority were established respectively under the Council of Ministers Regulation No. 156/2008, Regulation No. 151/2008 and Regulation No. 253/2011. The regulations have similar content and establish the River Basin High Councils and Authorities of the three river basins.

\subsection{Integrating information management, communication and conflict management}

The communication and exchange of information among higher and lower level river basin institutions, local actors and other institutions is the prerequisite for the dimensionally balanced and integrated water resources management and governance. Article 6(7) of the FDRE River Basin Councils and Authorities Proclamation No. 534/2007 deals with exchange of information. It states that Basin High Council has a duty to "provide information and advisory support to the body in charge of negotiating with neighbouring countries with respect to the basin where the basin is part of a trans-boundary basin".

Each basin authority has also a duty "to collect, compile, analyse and disseminate information for proper planning, administration and steering of water resources in the basin" (Art. 9/6). The authority also has a duty to prepare and provide necessary information for the concerned body in charge of negotiation on trans-boundary river basins on the basis of basin high council instructions (Art 9/11). It has also a duty to transmit compiled information with regard to the issuance of permits on water use to the Ministry of water resources (Art 15/2). 
The law requires the establishment of "Basin Information System". Every river basin authority is expected to develop and use the management oriented basin information system with the purpose to guide and support the "...basin water resources strategic planning and water management functions" (Art 16/1). The law indicates the indicators of the basin information. It includes the quantity and quality of water resources of the basin; the aquatic ecosystem of the basin; the level of water demand within the basin; the existing and planned major water infrastructures; the main interventions or projects that may have impact on the water resources; existing water uses; strategic orientations for actual implementation of integrated water resources management process based on the situation analysis; and means of implementing the plan, including implementing actors, action plans and budget requirement. ${ }^{100}$ The Proclamation requires water related activities of the stakeholders on any basin to be compatible with each basin plan (Art 16/3). Hence, establishing stakeholder's management plan is fundamental means to improve "... participation, cooperation, coordination and sharing responsibility". ${ }^{101}$

\subsection{The Establishment of Ethiopian Basin Development Authority: Towards IRBM or centralization of power?}

The Proclamation on the power and duties of the executive organs is repealed by a new Proclamation No. 1097/2018. The same also goes to the establishment of Ethiopian Basin Development Authority by a new regulation. In practical terms, the Authority is already established and the restructuring process is underway. There may not be substantial difference on the necessity of establishing river basin authorities in both proclamations. However, there can be a difference by whom the power should be held and who should exercise the power.

The objectives of the new Basin Development Authority (BDA) is to "... implement sustainable and integrated development, administration and utilization of the water resources at a basin level in equitable and participatory manner". ${ }^{102}$ It has numerous and illustratively listed powers and duties under the regulation which includes the power to undertake policy studies and researches to create conducive environment for the implementation of an integrated water resource management within basins. The authority will facilitate and undertake activities to promote IWRM, ensure that projects, activities and interventions

\footnotetext{
${ }^{100}$ FDRE River Basin Councils and Authorities Proclamation No. 534/2007, Art 16(2) (a-g).

${ }^{101}$ Awash Basin Authority (2017), supra note 3.

${ }^{102}$ Council of Ministers draft Regulation to define the powers, duties and organization of the Basin Development Authority, This Regulation is to be issued by the Council of Ministers pursuant to Article 5 and Article 34 of the Definition of Powers and Duties of the Executive Organs of the Federal Democratic Republic of Ethiopia Proclamation No. $1097 / 2018$.
} 
related to water in the basins are in line with the integrated water resources management process. ${ }^{103}$ The authority is also expected to work in collaboration with other stakeholders for "effective networking" through creating forums. ${ }^{104}$

Contrary to the previous powers and duties of river basin high councils and authorities, the regulation confers these powers and duties to Basin Development Authority (BDA). The establishment of this authority is seen as part of the undergoing national reform. The merger of the former three authorities into a single Basin Development Authority implies the tendency to centralize the previously decentralized powers and duties. Second, it evokes issues relating to the role of the former river basin high councils and authorities which are currently 'three branch offices' in their interaction with the Basin Development Authority. This structure is subject to critical questions. This structure seems to contradict with the hybrid approach or the empowerment of social basins in pursuit of the functional approach of water governance. This poses a question on how coordination occurs between the lower level management bodies and upper level or larger programs endorsed at the scale of a basin.

\section{Viable Policy Tracks}

\subsection{Innovative and adaptive governance towards empowerment and harmonization}

Empowerment may have human and social, political, economic, and cultural dimensions. Longwe (1991), outlines the useful distinctions between the different degrees of empowerment. ${ }^{105}$ First, it is the welfare 'degree' that tests whether basic needs are satisfied or not. Second, it is the access degree and this tests whether equal access to land, water or any other social service is assured or not. Third, it is the conscientisation and awareness-raising degree that tests whether structural and institutional discrimination is addressed or not. Fourth, it is the participation and mobilization degree that tests whether the equal taking of decisions is enabled or not. Fifth, it is the control degree that enables individuals to make decisions and the full recognition of such decisions. There is thus the need to promote and sustain these elements of empowerment with due attention to the balance in the context of tension between empowerment and cooperation.

Land governance tools in general and water governance tools in particular include core features of being pro-poor, equitable and gender-responsive,

\footnotetext{
${ }^{103}$ Art 5 (2\&3) of the draft regulation. It considers IWRM as a process.

${ }^{104}$ Id., Art. 5(12),

${ }^{105}$ S. Longwe (1991), 'Gender Awareness: The Missing Element in the Third World Development Project', in T. Wallace and C. March Changing Perceptions: Writings on Gender and Development. Oxford, UK: Oxfam.
} 
affordable, sustainable, full of subsidiarity, systemic and large scale. The criteria for assessing and promoting grass roots participation is to build among the existing networks, community processes, customs and norms. It calls for meaningful engagement at the grassroots. It addresses the challenges in the degree of participation, management of competitive interests, and reconciliation of local and technical knowledge. ${ }^{106}$ Capacities of development of the grassroots need to be tapped and they need to know how transparency in water management can be secured and corruption should be controlled. ${ }^{107}$

There are certain entry levels where to start to incorporate the integrated approach and the empowerment of local actors in basin management. First, it can be at local level and this includes the sub-basin scales. Second, it is the implementation level or basin or the provincial scale management plan. Third, it is the policy level where national or international processes can be helpful to implement the integrated approach and the empowerment at the grassroots. The Mekong River Commission was working with the National Mekong Committees in Lao PDR, Thailand, Cambodia and Viet Nam to foster participation. ${ }^{108}$ This was done by educating and raising awareness at the grassroots and stakeholders were also engaged at local and national level.

The power division in terms of shared power and self-rule may cause fragmentation and complexity in the management and regulatory functions. The actual decentralization, devolution or delegation of power from the centre can result in incompatibility, race to the bottom due to the differences in approaches, capacities, methods etc. among the settings of the localities within the regional setting. ${ }^{109}$ The formal and informal stakeholders and institutions existing in both the federal and state levels should thus be coordinated towards harmonization. The duty to cooperate should be installed in the inter-regional functions. Water resources or river basins are fluid and they delineate the fixed nature of local settings and impede uniformity in all spheres.

Any water governnace assessment should evaluate the laws and the degree of support put to the policy with clear separation of stakeholders' roles, responsibilities and manadtes. The same also goes to integrate the management

106 Through the process of interstate competition, other states and the federal government may move to adopt preferable approaches.

${ }^{107}$ United Nations Human Settlements Programme (UN-Habitat), (2012), Handling Land: Innovative tools for land governance and secure tenure.

${ }^{108}$ Global Water Partnership (GWP) and the International Network of Basin Organizations (INBO) (2009), supra note 93, p. 19.

${ }^{109}$ Reinhard Steurer and Christoph Clar (2015), 'Is decentralization always good for climate change mitigation? How federalism has complicated the greening of building policies in Austria', Policy Sci, 48: 85-107 
of water resources and river basins. The empowerment of the grassroots with all its degrees should be maintained at all levels of the linkages without hampering the harmonization process. The enablers for empowerment and the controllers for harmonization should thus be institutionalized by making a reform if it's necessary.

\subsection{Cooperation and balanced reconciliation}

Cooperation may have a narrower and broader conception. ${ }^{110}$ The narrower aspect may be expressed by the specification of minimum programs by a government. The federal government establishes minimum standards that states may opt to implement through programs that are no less stringent. There are two key elements: first, the fostering of state administrative programs and, second, the "delegation of tailored standard setting". ${ }^{111}$ Both elements operate under the oversight of the federal government. In contrast, the broader conception includes all programs with incentives for state and local jurisdictions for their role to advance federal law. There is a possibility for state favouritism or procedural favouritism among the units. ${ }^{112}$ The laws shall put the overall subject matters requiring mandatory cooperation or other related conditions.

In principle, all water uses should be reconciled in a balanced way. However, water resources and variation in economic, cultural and other spheres will determine the degree and weight of reconciliation on each theme. Contexts of each river basin will be determinant factors and the accompanying rationales for undertaking reconciliation in each level that should be sought by the governing bodies. On account of these, the reconciliation process should be done in a balanced way so that interests and dimensions are given due attention. The application of IWRM and IRBM approaches shall be promoted by the institutionalization and establishment of reconciliation agents. In this regard there may be the need for harmonizing some national standards at sub-national or local governments. For example, the Changjiang (Yangtze) Water Resources Commission (CWRC) of China has been the agent of reconciliation for more than a century. ${ }^{113}$

\footnotetext{
${ }^{110}$ Robert L. Fischman (2005), 'Cooperative Federalism and Natural Resources Law', Articles by Maurer Faculty. Paper 219, p, 189, available at $<$ http://www.repository.law.indiana.edu/facpub/219>. Last accessed on January 15, 2018, Citing Joshua D. Sarnoff, Cooperative Federalism, the delegation of federal power and the constitution.

${ }^{111}$ Ibid.

${ }^{112}$ Ibid.

${ }^{113}$ Global Water Partnership (GWP) and the International Network of Basin Organizations (INBO), (2009), supra note 93, p, 36.
} 


\subsection{Comparative experience on policy space to accommodate contexts}

There should be policy space for discussions on how to promote IWRM including functional and integrated approaches. This requires intergovernmental and local relations with policy space for experimenting ideas, practices or solutions etc. in the linkages. It is to be noted that river basin organizations pass through an evolutionary path with enlarging scale, ${ }^{114}$ and the availability of a policy space accommodates contexts. This will create an empowered decision making body and a room for bringing innovative ideas that are scaled and managed at higher level.

In general, there is ample experience in the establishment and operation of basin organizations to promote IWRM and IRBM through functional water governance approach. A syntheses document based on eight case studies, for example, explores the establishment of 'basin-scale organizations'. ${ }^{15}$ The document covers cases from Murray-Darling (Australia), Jaguaribe and Alto Tietê (Brazil), Fraser (Canada), Tárcoles (Costa Rica), Brantas (Indonesia), Warta (Poland) and Guadalquivir (Spain) river basins. The organizations had different structure and features. The basin organizations were primarily held by state companies (two cases), central government agencies "operating within nationally defined basin boundaries" (two cases), and there were some unique variations among the case studies. Four of the case studies had intergovernmental commission, quasi-governmental commission, non-governmental basin council, and hybrid basin committee/basin agency structures in each of the cases respectively. ${ }^{116}$

The most relevant lessons that can be drawn from these organizational set ups can be selected and adapted to Ethiopia. However, such selection of organizational set up of basin organization should promote IRBM and functional approach to water governance. The hybrid approach may be favourable to the Ethiopian case because it can assure the balance of interests, promote participatory approach, bring the integration of the higher and lower level functions, and reconcile the objectives of empowerment, cooperation and harmonization of laws and practices.

\footnotetext{
${ }^{114}$ Ibid.

115 Karin Kemper et al. (ed.) (2006), Institutional and Policy Analyses of River Basin Management Decentralization: The Principle of Managing Water Resources at the Lowest Appropriate Level -When and Why Does It (Not) Work in Practice, World Bank available at $<$ www.worldbank.org/riverbasinmanagement $>$. Last accessed on January 12, 2019.

${ }^{116}$ Ibid.
} 
In the absence of such balance through the hybrid approach, reliance on state (parastatal) companies may not accommodate varying interests. ${ }^{117}$ The possibility for empowerment will also be less practical. Primarily, they are companies and there is an embedded interest of making profit. This kind of structure assumes private ownership of water and considers water as an economic good. ${ }^{118}$ The second experience is establishing central governmental agencies at national level covering the boundaries of the basins. This kind of organization centralizes the power of governing and managing the water resources. It can be feasible to cooperate and harmonize such setups; but it can hamper the effort to promote empowerment and IRBM. It fails to accommodate participatory form of governance and decisions will also descend from top to the grassroots.

The third category of cases (in the case studies highlighted above) had shown the establishment of basin organizations at inter-governmental and quasigovernmental commissions. The establishment of commissions may not bring strong integration of the higher and lower level scales. And still the structure and power remains in the central government. The fourth category of the cases also shows establishing non-governmental basin councils. This is good to empower the grassroots and assure participatory approach. The power of government is taken and given to non-governmental basin councils. It gives recognition to the need of councils beyond the government wing. However, it may be a problematic structure on how both the government and nongovernment based councils interact and integrate for harmonized interventions. It takes the power of the government acting as a public trustee. In countries, such as Ethiopia, however, the technical role of the government is indispensable in facilitating cooperation in the context of harmonized interventions.

The last category of findings from the case studies avoids such onedimensional and side-lined structures and rather embodies hybrid basin committees or basin agency structures at different levels. This form of structure reiterates the underlying rationale of having some organizations not at a basin scale but at the "lowest appropriate level" for sustainable, efficient, participatory and equitable decisions and activities of IWRM. ${ }^{119}$ The appropriate level shall be determined after consideration of contexts. These forms of 'hybrid units' at sub-basin, regional, or local government levels are referred to as 'social

\footnotetext{
${ }^{117}$ Lorenzo Cotula (2014), "Study Addressing The Human Rights Impacts Of 'Land Grabbing, ”, Directorate-General For External Policies Of The Union Directorate B, Policy Department, EXPO/B/DROI/2014/06 PE 534.984

118 P. van der Zaag and H.H.G. Savenije (2006), Water as an economic good: the value of pricing and the failure of markets, UNESCO-IHE Institute for Water Education, Value of Water Research Report Series No. 19.

${ }^{119}$ Karin Kemper et al. (ed.) (2006), supra note 115.
} 
basins'. ${ }^{120}$ This helps to balance the dimensions of water governance and promotes integrated water management by integrating higher and lower level functions through reconciliation of the key and mediating factors.

With regard to the regulatory function of each basin organization, the authority given to each basin may vary. The comparative case studies show variation in the allocation of authority. ${ }^{121}$ Some of the organizations had the power to allocate water to users. There was also variation in regulatory and developmental functions of the organizations. But, all had a common function of planning and coordination which included the development of basin management plans and the coordination of activities among multiple governmental and non-governmental entities in each basin -based on the objective of promoting IWRM or IRBM.

\section{Conclusion}

The Ethiopian water governance system is top-down and almost all water resources governance issues are directed by the Constitution. Most issues of water management and water administration are delegated from the top or central organs. Although the Water Management Policy and the national water strategy documents have recognized the need for decentralized water management, the FDRE Constitution and the subsidiary proclamations do not support the decentralization of water management issues. They rather state that water management issues may be delegated to appropriate organs where it is necessary to bring efficiency.

The law-making power related with inter-regional state rivers is given to the HoPR. The power to determine and administer such linking rivers is given to the Federal government. This implies that there is no decentralized power on such linking rivers. In the existing legal frameworks starting from the Constitution and the subsidiary laws, it is not possible to exercise bottom-up governance approach. The policy and strategy partially seem better in accommodating water management decentralization even though there is broader definition of water management that contradicts with the Constitution and the subsidiary laws.

The laws do not facilitate grassroots empowerment in the decision-making process. Instead, decisions devolve from the centre for their implementation. In the course of grassroots empowerment, however, it is not possible to avoid conflicts in the local-local linkages unless there is harmonized linkage at the grassroots in the context of sustainable integrated watershed management. There have been conflicts in river basins that connect two or more than two regional

\footnotetext{
${ }^{120}$ Ibid.

${ }^{121}$ Ibid.
} 
states which can continue as a threat for future cooperation in the linkages in the absence of co-operative federal structure.

The currently designated institution, i.e., Ethiopian Basin Development Authority manifests the tendency of centralization, and there is no shared power that empowers the grassroots as active participants in decision-making processes. The tendency to bring legal unification by highly over-centralized or concentrated power in the federal government cannot bring efficient, equitable, democratic and sustainable water governance system.

As the experience of other states indicates, water governance in federal political settings should be based on the cooperative form of federalism. This helps to promote federalism and facilitates harmonization without disregarding legal pluralism. Reconciliation that ensures sustainable link at all levels and types of inter-governmental relations balances the dimensional interests and brings integration in water resource management. The reconciliation of tensions at levels and types of linkages should be backed-up by robust institutions and organizations. The hybrid governance approaches should thus be designed to promote the testing and experimentation of innovative ideas on water management. This is the most functional approach of water governance to promote cooperative federalism in water governance and balance the dimensional interests thereby ensuring IWRM though the reconciliation of empowerment, cooperation, and harmonization. A comprehensive national framework for IWRM is indeed essential for inter-regional state basin management. The FDRE water laws, policies, strategies are thus expected to be tested, amended, synchronized, and coordinated to facilitate an enabling space for the hybrid and functional water governance approach. 